\title{
A Revolução dos beatos, de Dias Gomes: a importância da literatura dramática na formação de um público leitor
}

\author{
The Revolution of the Blessed, by Dias Gomes: the importance of Dramatic Literature \\ in forming readership
}

\author{
Marcio da Silva Oliveira* \\ Universidade Estadual do Oeste do Paraná \\ Cascavel, Paraná, Brasil
}

Resumo: A formação de um público leitor crítico que busque a própria emancipação social passa pela valorização do ensino de literatura. O modo como a produção ficcional, em seu diálogo com a história, com a sociologia, com a filosofia, com a antropologia e com a cultura popular influencia na formação de uma consciência crítica é fator determinante para o desenvolvimento de uma civilização. A relação da literatura com a sociedade torna-se, assim, importante no processo educacional. Ainda mais quando dá voz a camadas marginalizadas e desconstrói discursos que consolidam situações de opressão e exploração. Levando em conta tais elementos, propõe-se aqui um trabalho que enfatize a necessidade de valorização da literatura, seja em ambiente escolar, seja nas outras diversas dimensões da vida social e humana. Para isso destaca-se aqui, por um lado, o papel do leitor no processo de recepção e significação do texto literário e, por outro, a urgente necessidade de incentivo à leitura do texto dramático, mais especificamente no teatro brasileiro, muitas vezes situado à margem dos outros gêneros. Para tanto, propõe-se, num primeiro momento, algumas considerações a respeito do ensino da literatura e, depois, uma breve análise da peça $A$ Revolução dos Beatos, de Dias Gomes, demonstrando as estratégias adotadas pelo teatro brasileiro para confirmar o texto dramático como fundamental à história da nossa literatura.

Palavras-chave: Literatura e Ensino. Gênero Dramático. Dias Gomes. Ficção e História.

\begin{abstract}
The formation of a critical reading public that seeks its own social emancipation goes through the valorization of the teaching of reading. The way how the fictional production, in its dialog with History, Sociology, Philosophy, Anthropology and the popular culture influences in the formation of a critical conscience is a determining factor in the development of a civilization. The relationship between Literature and society thus becomes important in the educational process. It happens especially when it gives voice to marginalized layers and deconstructs discourses that consolidate situations of oppression and exploitation. Taking these elements into account, this paper proposes a study that emphasizes the need to value Literature, whether in the school environment or in the other various dimensions of social and human life. For this, we highlight here, on the one hand, the role of the reader in the process of reception and meaning of the literary text and, on the other, the urgent need to encourage the reading of the dramatic text, more specifically in the Brazilian theater, often situated at the margin of the other genres. Therefore, it is proposed, at first, some considerations about the teaching of Literature and, after, a brief analysis of the play The Revolution of the Blessed, by Dias Gomes, demonstrating the strategies adopted by the Brazilian theater to confirm the dramatic text as fundamental to the history of our Literature.
\end{abstract}

Keywords: Literature and Teaching. Dramatic Genre. Dias Gomes. Fiction and History.

\footnotetext{
* Doutor em Letras pela Universidade Estadual de Maringá (UEM), atualmente em estágio de Pós-doutorado na Universidade Estadual do Oeste do Paraná (UNIOESTE), Cascavel, sob a supervisão do Prof. Dr. Gilmei Francisco Fleck, subsidiado pela Fundação Araucária do Paraná, pela Bolsa Produtividade em Pesquisa.
} 


\section{INTRODUÇÃO}

Vive-se, atualmente, no Brasil, tempos sociais e políticos conturbados, nos quais os próprios meios de comunicação se aparelham ao Estado, buscando maquiar, camuflar ou mesmo manipular a opinião pública a favor de um projeto de governo neoliberal e excludente. Nesse cenário, as manifestações artísticas, atreladas à prática de uma formação crítica de leitura, servem para a delimitação de estratégias contundentes de resistência frente aos desmandos do poder estabelecido. Mais do que isso, a busca pela qualificação de um público leitor favorece o estabelecimento de estratégias que desvelem as contradições que o estágio sócio-político atual desencadeia.

Para que isso aconteça é preciso, por um lado, que se enfatize o papel da literatura como agente transformador da sociedade e, em consequência, o papel do leitor como elemento constituinte do processo de significação do texto literário. São essas duas faces de uma mesma moeda capazes de moldar uma consciência crítica que possa resistir aos desmandos do poder estabelecido. Partindo dessa afirmação, torna-se urgente a busca de caminhos pertinentes de formação para que, em âmbito educacional, sejam criadas alternativas que visem à resistência mediante a construção de uma consciência crítica, que só é possível através de um bom projeto de formação do leitor. A valorização do processo de leitura, compreensão, interpretação e análise do texto literário é o ponto de partida para o embate frente ao superficialismo de ideias e ao antiintelectualismo militante que se tornou marca registrada de nossa época.

Dadas as bases do presente trabalho, busca-se aqui demonstrar que a literatura, mais do que um privilégio de quem a ela pode se dedicar por lhe ser garantido momentos de ócio, principalmente pelo grupo social privilegiado ao qual pertence, é um direito fundamental de qualquer sociedade que se pretenda mais coerente e consciente e que busca vias emancipatórias de sua população. Sendo assim, procura-se aqui, inserir na discussão a respeito da relação entre literatura e ensino o papel do teatro como agente formador e transformador da sociedade, com ênfase na necessidade de entender a função social da arte e a arte como agente de formação de um público efetivamente leitor. Para alcançar tais premissas, parte-se da ideia de literatura como direito imprescindível das pessoas, independente de classe social, crença, moral ou costume, seguindo-se a ideia de literatura dramática como elemento indissociável da criação estética presente no texto literário e, por fim, a análise da peça $A$ Revolução dos Beatos, de Dias Gomes, para que se percebam as estratégias utilizadas no texto teatral para que a criação estética dramática atinja seus objetivos literários.

\section{LITERATURA: O SONHO ACORDADO DAS CIVILIZAÇÕES}

O texto literário se organiza ao redor de uma estrutura discursiva, seja colocando em xeque certos tabus da moral dominante, extravasando estados de alma, ou mesmo problematizando ideias ligadas à instabilidade e desigualdade social. Diante dele, o leitor, em seu processo de identificação com sua própria vivência, atualiza-o, mostrando sua viabilidade, seja no âmbito individual ou no coletivo. Como destaca o crítico literário Umberto Eco: 
Um texto postula a seu destinatário como condição indispensável não somente de sua própria capacidade comunicativa concreta, mas também da própria potencialidade significativa. Em outras palavras, um texto se emite para que alguém o atualize, inclusive quando não se espera (ou não se deseja) que esse alguém exista concreta e empiricamente (ECO, 1979, p. 56).

A atualização do texto literário depende, desse modo, de um leitor que esteja apto a ressignificá-lo, que tenha a capacidade interpretativa suficiente para penetrar em seus meandros, emancipando-se frente a uma realidade que, constantemente, o oprime. $\mathrm{O}$ processo educacional que valorize a construção estética e ficcional é um dos caminhos mais viáveis para a realização desse processo emancipatório do indivíduo frente a seu meio social. Literatura e ensino constituem-se, assim, em elementos fundamentais à boa prática político-sócio-cultural.

A educação básica precisa partir desse pressuposto para que a formação realmente produza frutos. Procurando entender a necessária relação entre literatura e ensino, propõe-se aqui a inserção do texto dramático como eixo norteador do trabalho, demonstrando sua importância para a literatura e suas estratégias formais pertinentes à problematização político-social. Para isso, é preciso que se compreenda sua diferença a partir da distinção básica entre os três gêneros literários:

Podemos esboçar algumas características do gênero dramático, tomado como puro, em contraposição ao épico e lírico. Se na épica há um narrador que conta algo para alguém (numa comunicação implícita), no teatro vemos personagens em ação, emancipados de um narrador, conferindo a impressão de que a obra se narra por si só, sem interferência de qualquer espécie. Em contrapartida, na Lírica não há propriamente personagens, mas a manifestação imediata de uma emoção, de um sentimento, expressos por um Eu-Lírico. O tempo na Épica é, especialmente, o passado, onde se desenrola a história narrada, enquanto na Lírica se almeja um presente eterno, expressão de um sentimento válido em qualquer tempo. Já no teatro estamos diante de um presente que se desdobra em futuro pelo diálogo entre os personagens, base para o conflito dramático. Tudo deve advir da própria dinâmica da peça, pois qualquer remissão para fora dela ou mudança brusca deixa implícita uma organização da matéria, obra de uma instância narrativa que é alheia a essa estrutura (VILLIBOR, 2010, p. 20-21).

Gênero comumente situado, em âmbito nacional, à margem do canônico, o teatro brasileiro é analisado nesse artigo sob o âmbito da criação estética e, como tal, precisa corresponder à expressão das necessidades coletivas e à problematização dos eventos históricos. Forma e conteúdo, o modo como o teatro brasileiro, enquanto gênero dramático, apropria-se de elementos de outros gêneros literários com vistas à problematização social e as estratégias utilizadas pelo escritor para suscitar a formação de um público leitor são aspectos que são analisados neste artigo.

Em um contexto no qual a educação brasileira experimenta percalços dificilmente imaginados em recentes eras, principalmente no que se refere às ciências humanas, acusadas sistematicamente de manipuladoras e desintegradoras de uma (falsa) moral consolidada, torna-se mais urgente a discussão a respeito da importância da formação de públicos leitores em ambiente de sala de aula. Quando se verifica o grande descaso com 
a situação da educação no país, com destaque para os cortes de verbas do ano corrente, que afetam o financiamento estudantil, as bolsas de estudo e o incentivo à pesquisa em todos os âmbitos acadêmicos, muito mais do que necessário, é imprescindível que se discuta o papel da literatura na educação, principalmente, no referente à sua importância como elemento humanizador em tempos de barbárie.

Por que, diante de situações sociais tão precárias, em um momento em que a população sente faltar recursos básicos de sobrevivência, como alimentação, saúde e moradia, pensa-se na literatura como algo imprescindível? O que pode acarretar, diante de tanto descaso com a educação, a privação do aluno de elementos básicos que o tornem efetivamente um leitor? A literatura no ensino é, definitivamente, algo que pode fazer a diferença no que se refere à construção de uma realidade mais empática (o que não se ver em definitivo nos últimos anos)? Tais são os questionamentos que servem como norte ao presente trabalho que procura, dentro do âmbito literatura e ensino, enfatizar a necessidade da forma literária como fator preponderante de desenvolvimento humanitário.

Antonio Candido, em um artigo intitulado "O Direito à Literatura", busca responder ao questionamento a respeito do local do texto literário dentro da sociedade, ou seja, se a produção ficcional pode ser inserida na categoria dos bens indispensáveis e realmente necessários da vivência humana. Mais do que isso, se ela pode ser entendida como um direito tão fundamental quanto o direito de saciar a fome, de se vestir, de trabalhar, de ter uma moradia e acesso à saúde. Para isso, ele enfatiza o seu caráter de humanização, entendido por ele como "o exercício da reflexão, a aquisição do saber, a boa disposição para o próximo, o afinamento das emoções, a capacidade de penetrar nos problemas da vida, o senso da beleza, a percepção da complexidade do mundo e dos seres, o cultivo do humor." (CANDIDO, 2004, p. 180).

Entender a literatura como fator imprescindível na sociedade, segundo ele, está relacionado ao fato de que as criações ficcionais, sejam elas narrativas, líricas ou dramáticas, ocupam os mais diversos níveis das civilizações, desde formas mais populares, voltadas ao folclore, ao chiste ou à lenda, até as formas mais complexas de problematização e produção literária. Sendo assim,

[...] a criação ficcional e poética, que é a mola da literatura em todos os níveis e modalidades, está presente em cada um de nós, analfabeto e erudito, como anedota, causo, história em quadrinhos, noticiário policial, canção popular, moda de viola, samba carnavalesco. Ela se manifesta desde o devaneio amoroso e econômico no ônibus até a atenção fixada na novela de televisão ou leitura de um romance. Ninguém pode passar vinte e quatro horas sem mergulhar no universo da ficção e da poesia. Ora, se ninguém consegue passar vinte e quatro horas sem mergulhar no universo da ficção e da poesia, a literatura concebida no sentido amplo parece corresponder a uma necessidade universal, que precisa ser satisfeita e cuja satisfação constitui um direito. (CANDIDO, 2004, p. 174175).

As considerações de Candido a respeito da literatura, entendidas aqui em sentido amplo e sem levar a discussão para o âmbito do mérito literário, (se isso ou aquilo é ou não é considerado literatura), servem aqui, exclusivamente, para pontuar a sua necessidade no ensino. Mais do que isso, funciona como elemento constituinte do 
equilíbrio social e, portanto, imprescindível no âmbito educacional. Regina Zilberman e Ezequiel Silva, trazendo tal importância para a realidade de sala de aula, assim compreendem o papel da literatura nas escolas:

[...] compete hoje ao ensino da literatura não mais a transmissão de um patrimônio já constituído e consagrado, mas a responsabilidade pela formação do leitor. A execução dessa tarefa depende de se conceber a leitura não como o resultado satisfatório do processo de alfabetização e decodificação de matéria escrita, mas como atividade propiciadora de uma experiência única com o texto literário. (ZILBERMAN; SILVA, 2008, p. 23).

O ensino de literatura precisa, acompanhando as citações acima, desatrelar-se da ideia, ainda corrente no meio social, de que ela não constitui um direito como aqueles básicos acima mencionados ou ainda que se situa somente como uma parte do processo de alfabetização, resultado que comprova que o aluno sabe ou não decodificar o signo linguístico. Assim, é preciso que se discuta sempre o seu lugar, uma vez que a sociedade pode até afirmar que são privilégios bens fundamentais como comida, instrução, casa e saúde, mas ainda continuam com a ideia de que as classes mais pobres não precisam necessariamente ler Dostoievski ou Machado de Assis ou ouvir Mozart ou Beethoven, ou seja, tal acesso continua restrito às camadas mais ricas da população.

Com essa mentalidade, "a educação pode ser instrumento para convencer as pessoas de que o que é indispensável para uma camada social não o é para outra", ou seja, uma classe de trabalhadores que não esteja acostumada a folga em finais de semana ou ter acesso a uma alimentação que fuja do trivial não sentirão falta da sobremesa ou do descanso dominical. Tal raciocínio é direcionado para o exercício da literatura, uma vez que "O valor de uma coisa depende em grande parte da necessidade relativa que temos dela." (CANDIDO, 2004, p. 173).

E Candido afirma que, ao contrário do que querem incutir na cabeça dos alunos, temos muita necessidade de literatura. Dado seu caráter de confirmar ou negar visões de mundo, apoiar ou combater determinadas situações, propor ou denunciar discursos sociais ou crenças, desconstruir heróis, problematizar e desnaturalizar certas falácias e preconceitos relegados ao senso comum, ela nos incita a nos relacionar com os problemas da vida de modo sempre dialético, entendendo a sociedade em seus aspectos mais dinâmicos. A literatura é, por isso, instrumento poderoso de educação.

Quando se propõe a elaborar um texto literário, o poeta, dramaturgo ou romancista constrói uma obra cujo grande objetivo está em humanizar, não somente fazendo refletir o seu conteúdo no público leitor, mas levando esse público a fundir-se com a obra. Literatura não é reflexo da sociedade, mas é a própria sociedade, e a construção do autor, para Candido, é um modelo de coerência através da força da palavra organizada. Ou seja, o modo como o texto literário é organizado nos incita a organizar o nosso pensar, o nosso posicionamento diante da realidade e os nossos próprios sentimentos.

Para Alfredo Bosi, em seu livro Literatura e Resistência, pelo âmbito da ficção, lugar de excelência da história da literatura, é que se pode problematizar os processos histórico-culturais, refletindo-os nas vivências individuais e coletivas e desconstruindo certas visões dominantes de mundo que primam pela cristalização de injustiças. É a 
possibilidade de ruptura que emerge da formação de uma consciência crítica, para a qual a literatura é uma importante via de acesso:

Os escritos de ficção, objeto por excelência de uma história da literatura, são individuações descontínuas do processo cultural. Enquanto individuações, podem exprimir tanto reflexos (espelhamentos) como variações, diferenças, distanciamentos, problematizações, rupturas e, no limite, negações das convenções dominantes de seu tempo. (BOSI, 2002, p. 10).

Literatura e sociedade, assim, são indissociáveis, dependendo uma da outra sem que haja submissão de nenhuma parte. Ao levar o leitor à desnaturalização da realidade que o cerca, mostrando-lhe que a sociedade não pode ser vista de modo fixo, mas dialético, ela o retira de sua zona de conforto, do anestesiamento intelectual que é útil somente aos detentores do poder. Os escritos de ficção só ganham sentido quando encontram seu respaldo no meio social e essa relação, por muitos entendida como mero reflexo, é uma relação de interdependência. É o que afirma Otto Maria Carpeaux, em seu tratado História da Literatura Ocidental: "A relação entre literatura e sociedade não é mera dependência: é uma relação complicada, de dependência recíproca e interdependência dos fatores espirituais (ideológicos e estilísticos) e dos fatores materiais (estrutura social e econômica).” (CARPEAUX, 2008, p. 3).

O modo de organizar nossa mente e fornecer elementos para o fortalecimento de nossa visão de mundo no âmbito ficcional acontece porque as palavras, para Candido, são dispostas num todo articulado, sem o qual o impacto estético perderia seu valor. Assim, tanto quanto o conteúdo, a forma na qual o artista insere sua criação é que vai contribuir diretamente para esse impacto. Dentro da forma acontece o processo de humanização, principalmente porque dota as palavras de múltiplos significados.

Para destacar um exemplo dessa organização, Candido cita uma lira de Tomas Antônio Gonzaga, que trata de um assunto trivial, a saber, um poeta que anseia repousar no colo da amada contemplando as belezas da natureza. Uma situação amorosa que, mesmo correspondendo aos desejos de parte da população (um idílio amoroso), passaria despercebida, como vagas e informuladas evocações. Mas, dadas as estratégias utilizadas pelo poeta, como a disposição de rimas, a escolha e combinação das palavras, a sonoridade presente nelas, Gonzaga transforma aquilo que, por seu sentido vago, passaria despercebido, em produção estética: “o poeta transforma o informal ou o inexpressivo em estrutura organizada, que se põe acima do tempo e serve para cada um representar mentalmente as situações amorosas desse tipo." (CANDIDO, 2004, p. 179).

A forma, portanto, assegura tanto a generalidade do assunto quanto sua permanência e, sendo assim, a literatura se conecta com seu público de modo atemporal e de acordo com as formas que adota. Assim como a poesia, que se conecta com seus leitores, usando de suas peculiaridades, o gênero dramático também adota estratégias próprias para o seu público leitor e essas se diferem daquelas utilizadas tanto pelo gênero lírico, quanto pelo narrativo. A literatura dramática se constitui visando a sua representação em um palco, ou seja, é com vistas ao espetáculo teatral que ela se realiza. Anatol Rosenfeld, grande pensador do teatro, assim destaca as características e estratégias adotadas pelo gênero dramático: 
Como o texto dramático puro se compõe, em essência, de diálogos, faltando-lhe a moldura narrativa que situe os personagens no contexto ambiental ou lhes descreva o comportamento físico, aspecto, etc., ele deve ser caracterizado como extremamente omisso, de certo modo deficiente. Por isso necessita do palco para completar-se cenicamente. É o palco que o atualiza e o concretiza, assumindo de certa forma, através dos atores e cenários, as funções que na Épica são do narrador. Essa função se manifesta no texto dramático através das rubricas, rudimento narrativo que é inteiramente absorvido pelo palco. Fortes elementos coreográficos, pantomímicos e musicais, enquanto surgem no teatro declamado constituído pelo diálogo, afiguram-se por isso em certa medida como traços épicos-líricos, já que a cena se encarrega no caso de funções narrativas ou líricas, de comentário, acentuação ou descrição que não cabem no diálogo e que no romance ou epopeia iriam ser exercidas pelo narrador. O paradoxo da literatura dramática é que ela não se contenta em ser literatura, já que, sendo "incompleta", exige a complementação cênica. (ROSENFELD, 1985, p. 35)

Quando Rosenfeld enfatiza a ideia de gênero dramático 'puro' ele destaca as características de tal gênero, levando em conta que, embora tenha características próprias que são formuladas e exploradas em teorias a seu respeito, ele se constrói levando em conta dois fatores essenciais: primeiro, sua escrita sempre visa à complementação cênica, ou seja, mesmo que nunca seja representado ele é elaborado para tal fim, sendo assim, dá prioridade ao diálogo, o aspecto narrativo é substituído por marcações cênicas, o espaço do desenvolvimento do enredo é, normalmente, restrito para que caiba no palco, assim como as disposições da trama no tempo; mesmo assim, o texto dramático não se restringe às características acima mencionadas e, por isso, pode adotar em seu entrecho elementos retirados tanto do gênero lírico, com a deflagração das emoções, quanto do narrativo, com a presença, mesmo que sutil, de um narrador que conduz a história e demarca os variados discursos e visões de mundo das personagens.

Há sempre aspectos dentro do texto dramático que não cabem no diálogo e, por isso, a presença da lírica e da narrativa são, muitas vezes, adotadas em seu entrecho. A ideia de incompletude do gênero dramático significa que ele precisa ser elaborado de tal maneira que só se complete no palco, que seja direcionado à sua representação. Entretanto, certos elementos não cabem em diálogos e rubricas, sendo, portanto, imprescindível o seu envolvimento com os demais gêneros literários.

A caracterização do gênero dramático como destacado acima "refere-se a um 'tipo ideal' de drama, inexistente em qualquer realidade histórica, embora haja tipos de dramaturgia que se aproximem desse rigor." (ROSENFELD, 1985, p. 36). Interessa-nos aqui muito mais essa aproximação do gênero com a realidade histórica do que a análise de seus recursos formais de modo mais rigoroso. O leitor que se coloca diante de um texto narrativo e um dramático compreende, de imediato, a forma de ambos, ou seja, enquanto no primeiro temos o narrador como intermediário entre o receptor e os acontecimentos, no segundo, esse intermédio é dispensado e os acontecimentos são mostrados pelos atores que desempenham um papel no palco. Além disso, no texto teatral, temos a presença das marcações cênicas, como já destacado, e das indicações espaciais e temporais. Todos esses elementos precisam ser assimilados pelo leitor, como 
chave de leitura, para que a relação receptor/texto aconteça de maneira fluida e satisfatória.

Assimilando os elementos formais do texto dramático, o leitor pode, desse modo, partir para níveis mais aprofundados de análise, a saber, as demarcações discursivas, as intenções interpretativas e a crítica histórico-sócio-cultural. A demarcação discursiva, a relação do texto com a história e com a sociedade e as estratégias adotadas pelo autor e que exigem a participação do leitor no processo de significação do texto tornam-se aspectos imprescindíveis na análise que se propõe a seguir. O objetivo do presente trabalho é destacar como o gênero dramático contribui de modo pertinente aos estudos de literatura no que se refere à sua importância no ensino e à formação do leitor.

Sobre a questão da demarcação discursiva, presente não somente no gênero dramático, mas no fazer literário como um todo, Dias Gomes, importante dramaturgo brasileiro, autor de peças importantes como O Pagador de Promessas, O Santo Inquérito e $O$ Bem Amado, assim analisa a função do teatro e as estratégias utilizadas para sua consolidação:

Em primeiro lugar, devemos levar em conta o caráter do ato político inerente a toda representação teatral. A convocação de um grupo de pessoas pra assistir a outro grupo de pessoas na recriação de um aspecto da vida humana, é um ato social. E político, pois a simples escolha desse aspecto da vida humana, do tema apresentado, leva o autor a uma tomada de posição. Mesmo quando ele não tem consciência disso. [...] Toda escolha importa em tomar um partido, mesmo quando se pretende uma posição neutra, abstratamente fora dos problemas em jogo, pois o apoliticismo é uma forma de participação pela omissão. Pois essa favorece o mais forte ajudando a manter o status quo. Toda arte é, portanto, política. A diferença é que, no teatro, esse ato político é praticado diante do público. Essa é a característica essencial da função dramática: ela acontece. É presente, não passado. Ao contrário da pintura, da escultura, da literatura ou mesmo do cinema, que já aconteceram quando são oferecidas ao público, o teatro possibilita a este testemunhar, não a obra realizada, mas em realização. E, sendo testemunha, como num julgamento, influir nela. Além disso, o teatro é a única arte (no meu entender, a dança também é teatro) que usa a criatura humana como meio de expressão. Esse meio de expressão [...] torna o teatro a mais comunicativa e a mais social de todas as artes (GOMES, 2012, p. 31-32).

Ao enfatizar a diferença entre a arte teatral e as outras artes, no que se refere à sua função social, o dramaturgo coloca em primeiro plano a sua importância aos estudos históricos, filosóficos, sociológicos, antropológicos e, claro, literários. É o que destacamos abaixo com a proposta de análise da peça $A$ Revolução dos Beatos, de Dias Gomes.

\section{A REVOLUÇÃO DOS BEATOS: PROPOSTA DE ANÁLISE DO TEXTO DRAMÁTICO}

Na educação básica, geralmente quando o aluno inicia seus estudos literários, é-lhe apresentado um panorama geral da história da literatura, levando em conta as principais características de cada escola e os autores consagrados nos períodos em que essas manifestações estavam vigentes, com seu início, auge e decadência. Trata-se, 
normalmente, de um estudo pautado num acompanhamento histórico, que enfatiza escritores considerados fundamentais e que, por isso, enquadram-se numa espécie de lista canônica mais pela complexidade de sua escrita do que pela pertinência da mesma com a vivência social.

Com tal afirmativa, não estamos aqui apresentando somente uma crítica aos grandes escritores da literatura, tampouco à necessidade de se conhecer os movimentos literários através do tempo. Ao contrário disso, sabemos da importância de tais manifestações para a consolidação de um ideário crítico frente aos desmandos de um poder estabelecido através dos tempos. O que está em questão é o fato de que, normalmente, tal acompanhamento histórico acontece, em ambiente escolar, sem qualquer esforço de conexão com a vivência cotidiana das pessoas, ou seja, um conteúdo que é transmitido quase sempre de modo autômato e que, por isso, encontra tanta resistência por parte dos alunos. Os alunos da educação básica, dessa forma, deixam de gostar de literatura por não perceberem nela qualquer vínculo com sua vida social ou seus anseios diante do mundo.

Podemos destacar como exemplo o modo como Machado de Assis, indubitavelmente um dos grandes escritores de nossa literatura, é explorado em sala de aula. Na maioria das vezes, as reclamações dos alunos por terem que ler os romances machadianos se refletem na maneira como esses lhe são apresentados: palavras obsoletas, estilo complicado, difícil leitura. Assim, a obrigatoriedade de leitura de autores como Machado, somado à dificuldade que o aluno tem de interpretar certos textos clássicos e ainda a redução das aulas de literatura em panorama histórico e estudo de características das escolas literárias, faz com que esse aluno vá, gradativamente, perdendo o interesse pelo assunto. Quando a literatura se torna somente uma das disciplinas que o aluno precisa transpor para não ver perdido seu ano letivo, a prática da leitura, tão importante à sua formação, fica totalmente comprometida.

$\mathrm{O}$ ensino de literatura, mais do que a apresentação de autores canônicos e características de escolas, precisa ser espaço para a formação de uma consciência crítica, como destacamos na primeira parte do artigo, e que leve o aluno a adquirir a capacidade de ler, compreender, interpretar e analisar a realidade à sua volta. $\mathrm{O}$ seu processo de emancipação social depende disso, caso contrário, as escolas estarão somente formando indivíduos autômatos, incapazes de se posicionar diante da realidade e, portanto, massas de manobra em uma realidade permeada de injustiças em todos os níveis.

A literatura precisa estar conectada com a vida social. O seu conteúdo precisa colocar o aluno em estado de desconforto frente à realidade para, com isso, buscar alternativas de transformação social e de sua própria vivência individual. É por isso que ela, a literatura, precisa ser ensinada, levando em conta seus vínculos com a história, a sociologia, a antropologia, a filosofia, etc. O texto literário é um aparato indispensável que leva o autor a compreender o mundo dialeticamente e isso precisa ser assimilado pelo leitor, sendo instrumento de transmissão daquilo que, por si só, ele não consegue expressar. Desse modo,

[...] na leitura e na escritura do texto literário encontramos o senso de nós mesmos e da comunidade a que pertencemos. A literatura nos diz o que somos e nos incentiva a desejar 
e a expressar o mundo por nós mesmos. E isso se dá porque a literatura é uma experiência a ser realizada. É mais que um conhecimento a ser reelaborado, ela é a incorporação do outro em mim sem renúncia da minha própria identidade. No exercício da literatura, podemos ser outros, podemos viver como outros, podemos romper os limites do tempo e do espaço de nossa experiência e, ainda assim, sermos nós mesmos. É por isso que interiorizamos com mais intensidade as verdades pela poesia e pela ficção. (COSSON, 2014, p. 17).

Partindo, assim, desses elementos que precisam compor o ensino de literatura, propomos uma análise literária que enfatize essa necessidade de identificação entre o indivíduo e o mundo ao qual pertence. Para isso, destacamos um gênero literário que, normalmente é situado à margem do canônico, principalmente na literatura brasileira, para se notar o quanto é importante a leitura do texto que leve em conta as estratégias do autor, no conteúdo e na forma, para aguçar as capacidades interpretativas do leitor. Trata-se aqui de $A$ Revolução dos Beatos, de Dias Gomes, peça publicada e encenada pela primeira vez em 1962.

Dias Gomes, normalmente conhecido por ser autor de telenovelas, conseguiu percorrer de modo contundente pelas trilhas da ficção, transitando entre o cinema, o rádio, a televisão e, principalmente, o teatro. Dentre suas peças mais conhecidas destacam-se O Pagador de Promessas (1960), O Bem Amado (1962) e O Santo Inquérito (1967). Crítico ferrenho da realidade social, procurou inserir, em sua produção ficcional, a camada marginalizada da população, dando-lhe voz diante de contextos pautados pela injustiça e a desigualdade. Através de suas peças, destaca-se o processo de deslegitimação da opressão mediante o desmascaramento de certos discursos consolidados que a favorecem. Assim, Gomes dá voz ativa ao operário, ao retirante, ao trabalhador rural, à prostituta, enfim, aos indivíduos oriundos das camadas mais miseráveis. É o que se verifica na peça $A$ Revolução dos Beatos objeto de análise do presente artigo.

A forma do texto dramático é, como escrito acima, diferente da do épico e do lírico. Para seu pleno desenvolvimento, o escritor adota certas estratégias que exigem a plena aceitação do leitor: a primeira e mais significativa é o fato de que o texto dramático ultrapassa os limites do texto, ou seja, é sempre feito com vistas à sua encenação. Sendo assim, o texto dramático se consolida no palco, é teatral. Para isso, como foi destacado, o narrador está ausente e a ação se desenvolve mediante diálogo direto das personagens. $\mathrm{Na}$ apresentação teatral tradicional, o palco apresenta uma quarta parede, invisível, que separa os atores do público e os transforma em personagens, que criam a ilusão, representando como se vivessem a trama sem a existência do público. Como destaca Peter Szondi (2001, p. 31):

[...] este [o público] assiste à conversão dramática: calado, com os braços cruzados, paralisado pela impressão de um segundo mundo. Mas sua passividade total tem (e nisso se baseia a experiência dramática) de converter-se em uma atividade irracional: o espectador era e é arrancado para o jogo dramático, torna-se o próprio falante (pela boca de todas as personagens, bem entendido). A relação espectador-drama conhece somente a separação e a identidade perfeitas, mas não a invasão do drama pelo espectador ou a interpelação do espectador pelo drama. 
Em contraposição ao drama tradicional, destaca-se o teatro épico cujo objetivo está essencialmente na quebra dessa ilusão (quarta parede) e que marca a invasão do drama pelo espectador, ou seja, o público torna-se participante do processo de significação da peça. O épico formulado por Bertolt Brecht (1898-1956) se contrapõe ao teatro aristotélico porque apresenta um novo panorama das relações sociais, ou seja, enquanto para a tragédia grega, por exemplo, os enredos denotam aspectos universais e atemporais, do herói que assume para si a responsabilidade sobre os eventos trágicos, provocando um efeito catártico no púbico, o sujeito do teatro épico é fruto de seu momento histórico e, desse modo, é movido por determinantes sociais. Enquanto para o drama tradicional, as personagens vivem no lugar do público, sofrem os eventos para que o espectador experimente um movimento catártico, o épico transforma o espectador em observador e crítico, desperta-lhe a atividade.

Nesse sentido, Brecht defende um teatro engajado socialmente, no qual o elemento narrativo (épico) quebra a ilusão do drama tradicional e transforma o palco em tribuna, exigindo a participação do público. Utilizando-se de expedientes como o abandono do espaço fictício, apresentam-se breves narrativas e falas direcionadas ao espectador, incentivando-o à reflexão. Essas são as bases da dramaturgia moderna, com a presença, não mais de uma mera personagem, mas de um ator/narrador que impede a passividade do espectador/leitor.

O teatro épico mostra-se, logo, narrativo; diverge totalmente do teatro dramático, no qual não havia um deus ex machina e ninguém contava a história; as personagens a viviam, em vez de contá-la. O autor, no teatro épico, manipula a ação, faz saltar o tempo, seleciona os acontecimentos, cenas e lugares (ROSENFELD, 2009, p. 300).

Mais do que somente abrir uma conexão com o público, o teatro épico não prioriza um espaço e um tempo determinado, mas, dado seu caráter narrativo, permite a expansão espaço-temporal, possibilitando, com isso, a exploração de várias esferas de um mesmo discurso, utilizando de expedientes como apresentação de slides, uso de estatísticas, diálogo direto com o público, trânsito entre diferentes manifestações artísticas. Por fim, a dialética, dentro do teatro épico, questiona a naturalização e imutabilidade dos processos sociais. Quando as relações sociais deixam de ser discutidas tornam-se naturais e isso, ao mesmo tempo, aliena e consolida a ideologia do poder dominante.

No épico, as tradições são questionadas, podendo ou não ser validadas e os valores cristalizados, tomados como verdades incontestáveis, abrem-se para novas possibilidades de posicionamentos ideológicos. Diante de tudo isso, o espectador/leitor deixa de se sentir apenas como dentro de algo, como no caso do drama tradicional e o drama burguês, mas diante de algo, participante do processo e, por isso, ativo na recepção e ressignificação do texto. Valores escamoteados pelo sistema dominante tornam-se objetos de análise e desconstrução.

Essa diferenciação entre o drama tradicional e o teatro épico é pertinente aqui para que o leitor, ao adentrar no texto dramático, tenha condição necessária de notar o que o escritor/dramaturgo apresenta como chave de leitura: se se trata de um texto 
teatral em chave dramática ou em chave épica. Isso faz com que a análise de conteúdo de uma peça teatral, em especial, do teatro brasileiro moderno, torne-se mais contundente e satisfatória. Além disso, para um público leitor de educação básica, a inserção no processo de leitura do texto dramático precisa partir de seus elementos básicos, desde sua forma, passando pela marcação discursiva, pela situação do narrador, pelo ação marcada pela objetividade do diálogo das personagens e, claro, pelas marcações de cena ou rubricas que apontam ou sugerem o modo como se dará sua representação no palco. Sendo assim, analisamos a peça de Dias, levando em conta três aspectos básicos: a sua chave de leitura, a sua construção formal e a análise de seu conteúdo.

A Revolução dos Beatos é uma peça de Dias Gomes publicada em 1962 e encenada nesse mesmo ano pelo Teatro Brasileiro de Comédia (TBC). Nesta comédia, o autor trabalha com elementos de desconstrução do mito, mesclando personagens fictícias e históricas e analisando criticamente no palco as consequências do messianismo no Nordeste brasileiro. Construída em chave épica, a peça é dividida em 3 atos e 14 quadros, nos quais o autor trabalha com a temática da religiosidade primitiva, não de modo a somente apresentá-la objetivamente, mas propondo uma análise crítica, de modo a desvelar a indústria da miséria propagada em forma de prenúncio do fim dos tempos (messianismo) e manifesta na concentração de retirantes, aleijados e moribundos na cidade de Padre Cícero de Juazeiro, ansiosos por um milagre do santo homem.

O assunto da peça remete ao ano de 1920, contexto no qual se trava uma verdadeira guerra civil em grande número de cidades nordestinas, por causa da concentração em massa de miseráveis retirantes e pessoas assoladas pelos mais diversos tipos de doenças. Soma-se a isso a situação da seca, a incursão constante dos cangaceiros e a exploração do trabalho escravo pelos coronéis, devida principalmente ao fluxo infindável de peregrinos. Temos, assim, o cenário propício para a consolidação do fanatismo e para a exploração econômica da miséria. Essa situação de opressão é demarcada pelo dramaturgo em chave cômica, aproximando o ficcional do histórico.

Utilizando-se de aspectos da cultura tradicional nordestina, como o bumba-meuboi e o cordel, o enredo da peça trata da exploração política do fanatismo popular e da tomada de consciência (mesmo que fraca e dúbia) do indivíduo frente a essa situação de opressão. Tendo Juazeiro no Ceará como cenário, a ação da peça acontece do seguinte modo: um enorme grupo de retirantes, doentes e toda a gama de miseráveis, reúne-se nas cercanias da propriedade de Padre Cícero (prefeito e grande detentor de terras) em busca de milagres. Adoentado, o padre deixa a cargo de seu secretário, Floro Bartolomeu, a atendimento dos romeiros, para se poupar com vistas à campanha política que se aproxima. Bastião, trabalhador humilde, tenta marcar um encontro com o padre para que ele lhe conceda a graça de um arranjo amoroso com Zabelinha, mas, dada a ausência do religioso, faz o pedido a seu Boi Simpático, presente de romeiro. Ele oferece ao boi o melhor capim verde em troca de seu desejo e, ao ser atendido, procura dar capim roubado para o boi, que o recusa. $\mathrm{O}$ fato de um boi recusar alimento roubado somado ao desejo atendido faz com que a notícia do milagre se espalhe, tornando santo o animal, que começa a receber romeiro de todas as partes, competindo diretamente com o padre. 
Diante de tal quadro, Floro Bartolomeu, vendo a ameaça do animal à suas pretensões políticas, que contava com a ajuda de Padre Cícero (ótimo cabo eleitoral), organiza certas artimanhas para que, tanto Bastião quanto os demais romeiros reneguem o boi, oferecendo àquele algumas recompensas. A recusa do matuto faz com que Floro incentive o padre a sacrificar o animal em praça pública, dividindo opiniões e levando parte da população a defendê-lo contra o batalhão do padre e do político. Prisões e mortes levam Bastião a concluir que o boi não opera milagres a favor dos romeiros e, com isso, começa a se conscientizar a respeito das consequências do fanatismo que despertou tal situação e, com isso, acaba, ele próprio, por sacrificar o animal.

Como se nota pelo enredo, trata-se de uma peça de cunho satírico, que se utiliza da comédia para criticar uma situação de opressão, consequência do uso da religião como ferramenta política. Dados os elementos do enredo, nota-se de modo bastante contundente o fato de que o dramaturgo procura uma forma que enfatize os aspectos da cultura popular nordestina, dentro de um texto que valoriza a linguagem do povo, suas manifestações artísticas, a dança, a poesia, e, claro, suas crenças. Sendo assim, ele procura inserir no centro do palco as camadas marginalizadas em uma linguagem que o povo, protagonista, entenda e se identifique. No prefácio da peça, Dias Gomes escreve:

Esta é uma tentativa de Teatro Popular. Tentativa para encontrar uma forma brasileira para esse tipo de Teatro, no qual o Povo se sinta representado, pesquisado, discutido e exaltado, em forma e conteúdo. Parece-me desnecessário dizer que esse Teatro, além de popular, é também político - não poderia deixar de sê-lo. Se escrevemos para o Povo, uma pergunta se impõe: a favor ou contra? Pois não é possível ficar neutro com relação a ele. Como Povo, entendemos a massa oprimida. Se lhe apontamos caminhos para livrar-se da opressão, se o armamos contra o opressor, estamos a seu favor; se apenas o distraímos - e por consequência o distraímos da luta - estamos contra ele. Não há neutralidade possível. (GOMES, 1990, p. 145).

Como se verifica, o dramaturgo já insere na introdução da peça uma chave de leitura para se compreender tanto a sua forma (de teatro popular) que mesmo adequada aos moldes do drama tradicional, com atos, cenas e quadros, rubricas etc., apresenta características épicas com o uso de recursos advindos de outras artes e gêneros como veremos a seguir; quanto a seu conteúdo, de crítica a uma situação de opressão, de desmascaramento de um discurso dominante que se nutre da miséria e, principalmente, de necessidade de instruir (não distrair) aqueles com poucos ou nenhum direito a um processo educacional de qualidade.

Sobre a forma, pode-se afirmar que Dias Gomes segue as trilhas do drama tradicional, mas não de maneira literal. Ele obedece à inserção de rubricas para a orientação do leitor/espectador, divide o enredo em cenas e quadros e dispõe as personagens linearmente, demarcando a trama através do diálogo direto, sem intermédio do narrador. Entretanto, a figura do narrador aparece na peça mediante recursos épicos adotados pelo dramaturgo para demarcações de discursos e a crítica social. Além disso, essa função épica é ainda percebida no trânsito que o escritor faz da representação dramática com outras artes, por exemplo, o cinema e a literatura de cordel. 
Já no primeiro quadro, propositalmente curto para funcionar como uma introdução ao assunto, Gomes destaca esse trânsito entre as artes. Lembrando o teatro de Piscator ${ }^{1}$, ele apresenta no início da peça um telão no qual, em forma de estatística, mostra a real situação da cidade de Juazeiro: "População: 20.000 habitantes; milagres: 1302; escolas: 2; crianças sem escola: 94\%" (GOMES, 1990, p. 37). Com ironia, demarca, por um lado, a desvalorização da educação e, com ela do senso crítico e, por outro lado, o apego exagerado às pregações, ameaças e promessas dos charlatões da fé. Assim, “[...] apoiado por alguns elementos periféricos, A Revolução dos Beatos introduznos no centro mesmo do fanatismo religioso." (ROSENFELD, 1982, p. 63).

A seguir, o vendedor de orações declama para o público uns versos para introduzir o assunto da peça, nos moldes dos cantadores de $\operatorname{cordel}^{2}$ e que apresenta uma breve biografia de Padre Cícero, de seus milagres e da relação dos habitantes de Juazeiro com o 'santo' homem: “[...] que meu Padrim é um santo/ Isso tá mais que provado/ Basta atentar os milagres/ Que ele tem realizado [...]." (GOMES, 1990, 37). Todos esses elementos precisam ser assimilados pelo leitor para que ele perceba de imediato a chave de leitura que Dias Gomes propõe, a saber, que a parte introdutória da peça, embora pareça elogiosa ao padre é colocada ali de maneira irônica, em contraposição às estatísticas apresentadas em forma de slides, para enfatizar o nível de misticismo popular (que desencadeia o fanatismo) que cerca a vida do clérigo.

Tais elementos serão mais enfatizados nos quadros e cenas que seguem, pois, a peça apresenta um retrato mordaz do Padre Cícero, então proprietário de terras e prefeito da cidade, com visão retrógrada no que se refere à educação: "PADRE: o homem não precisa de tantas escolas para chegar até Deus." (GOMES, 1990, p. 94). Com o objetivo de crítica ao movimento messiânico que se formou ao seu redor, propício à comercialização da miséria, o padre é colocado como figura manipulada pelo doutor Floro Bartolomeu, seu orientador político, cujos interesses eleitoreiros demarcam na peça uma tipificação do populismo que comumente se instaura em regiões assoladas pelo caos social, e esse é o caso das regiões áridas do Nordeste.

\footnotetext{
${ }^{1}$ Erwin Piscator é o criador do chamado Teatro Político e, posteriormente, do Teatro Didático, que influenciou na formulação do Teatro Épico de Brecht. Trata-se de um teatro voltado para a razão do espectador e, por isso, precisa se apoiar em recursos que o tornem educativos, tais como elementos que transcendam o palco e dialoguem diretamente com o espectador e seu momento histórico (documentos, reportagens, notícias de jornal, etc.). "Para Piscator, o teatro era um parlamento e o público uma associação legisladora. Ao parlamento foram levadas plasticamente as questões públicas que era preciso resolver. [...] O teatro tinha uma ambição: colocar o seu parlamento, o público, em situação de, baseado em ilustrações, estatísticas, palavras de ordem, tomar as suas decisões. O teatro de Piscator, embora não renunciando o aplauso, pretendia, mais ainda, uma discussão. O que desejava não era apenas proporcionar aos espectadores uma vivência, senão também obriga-los a tomar uma resolução prática, a de participar ativamente da vida" (DREWS, 1962 apud PISCATOR, 1968, p. 5).

${ }^{2}$ Enquanto manifestação cultural, a Literatura de Cordel se espalhou pelo Brasil, em especial, na região Nordeste, tendo por base a transmissão e discussão das condições sociais das classes marginalizadas e seus fatores determinantes. Entre esses fatores destacam-se "a organização da sociedade patriarcal, o surgimento de manifestações messiânicas, o aparecimento de bandos de cangaceiros ou bandidos, as secas periódicas provocando desequilíbrios econômicos e sociais. As lutas de famílias deram oportunidade, entre outros fatores, para que se verificasse o surgimento de grupos de cantadores como instrumentos do pensamento coletivo, das manifestações da memória popular" (DIÉGUES JR., 1977, p. 6).
} 
Para Rosenfeld (1982, p. 64), "Floro, personagem cuidadosamente elaborado, é o modelo do político beneficiado por estruturas interioranas atrasadas e pelo eleitorado cabresteiro." Tanto Floro como o padre Cícero são figuras históricas inseridas em um enredo ficcional e, nesse sentido, para Rosenfeld, a peça é elaborada com vistas a demonstrar a verdade da ficção, mais profunda. O cinismo de Floro manifesta-se em sua obstinação em tirar maior proveito possível da amizade com o padre que, por sua vez, detém os flagelados sob sua 'proteção' e, assim, usar do conhecimento adquirido para manipular, assumir o poder, reprimir, escravizar e oprimir.

A rubrica que abre o segundo quadro, mais do que mera marcação para a representação teatral, exerce a função narrativa de destacar o que há por trás da relação que se estabelece entre o padre, seu orientador político e a população de miseráveis.

Rua em frente à casa do Padre Cícero. É uma casa baixa, com uma janela gradeada. Tanto a porta como a janela estão fechadas. Os ROMEIROS, uns sentados outros de pé, entre eles alguns doentes e aleijados, aglomeram-se diante da casa, à espera da bênção do "Padrinho". Sujos e abatidos trazem chapéus de couro ou de palha de carnaúba, alpargatas amarradas à cintura ou pendentes do cano do rifle. De vez em quando, um deles se aproxima da casa do Padre e beija o portal. Um MORIBUNDO, deitado numa rede sustentada nas extremidades por dois ROMEIROS, geme angustiosamente. Um FANÁTICO, de joelhos, reza, enquanto bombas e foguetes espoucam aos gritos de "Viva meu Padrim!" (GOMES, 1990, p. 39).

Nesse trecho, o leitor precisa se atentar para as estratégias formais de Gomes, que transcendem à forma pura do texto dramático, na qual a rubrica tem a função de demarcar espaço e tempo. Aqui, mesmo apontando o espaço no qual se desenvolve a trama, ressalta-se a forte intenção de crítica social, na qual uma multidão de miseráveis idolatra um padre com objetivos escusos. Trata-se da desconstrução de um mito apontada desde as linhas iniciais do texto.

Em $A$ Revolução dos Beatos, dois elementos desencadeiam a ação dessa peça: o primeiro é a existência de uma promessa, partindo de Bastião para conquistar Zabelinha; o segundo é a presença de um animal, um boi, com função indispensável aos propósitos cômicos do enredo. Nesse caso, como vimos acima, a graça pedida por Bastião é alcançada quando este, dada a impossibilidade no momento de recorrer ao padre, promete roubar capim fresco para o Boi Simpático, de propriedade do vigário. Quando o boi recusa o alimento por ser roubado, inicia-se um processo de romaria ao estábulo para súplicas ao animal milagreiro que, assim, torna-se mais popular que Padre Cícero. O cuidador do animal, Mateus, aproveitando da situação, passa a vender fezes, secreções e pelos do animal, o que por si já denota o ridículo da situação que se torna ainda mais cômica quando Floro, percebendo o potencial político do boi, vê nele um adversário a seus planos, que precisa ser eliminado. Como destaca Rosenfeld (1982, p. 66):

Uma das mais profundas raízes do cômico, o desajustamento e o choque entre os fins humanos e as cegas leis causais da natureza, que escapam do controle humano e the frustram os planos, é explorada com maestria por Dias Gomes: os objetivos espertos de Floro quase naufragam por causa de um Boi. No fundo, porém, é o quadrúpede irracional 
que tem razão, representante que é do povo. Este, graças a ele, tem, de um modo errado, a intuição certa de que Floro não defende os interesses do povo.

Bastião, nesse sentido, é a personagem que representa na peça essa fraca tomada de consciência popular frente aos desmandos do poder estabelecido, marcado pelo coronelismo que se aproveita do flagelo da seca para escravizar as massas. Mesmo ainda apegado às tradições religiosas arcaicas e, pelo fato de ser ele mesmo a iniciar o processo de adoração ao quadrúpede, Bastião é a personagem que, gradativamente, vai tomando consciência dos desmandos provocados por Floro e o padre, o que não significa que desperte, com sua conscientização, uma revolução popular.

E o leitor é incitado a acompanhar esse processo sem, no entanto, cair no anestesiamento que, como aponta o próprio Gomes, mais distrai do que instrui. Assim, ao final da peça, não se tem um levante das classes marginalizadas e, tampouco, a punição dos responsáveis pela opressão. Tal efeito catártico não atenderia aos propósitos da peça, ou seja, transcender o livro/palco e levar o desconforto para o leitor/espectador em forma de desnaturalização de uma situação de injustiça. Mediante o contato com o texto, o leitor precisa compreender as estratégias de poder que alimentam as engrenagens e que, em consequência, legitimam a opressão, seja pela indústria da miséria, seja pela incitação ao fanatismo que, de certo modo, tornam-se duas faces de uma mesma moeda.

\section{CONSIDERAÇÕES FINAIS}

Como viemos acompanhando até aqui, a penetração no texto literário precisa levar o leitor, desde os primeiros contatos com a literatura em ambiente escolar, a dar-se conta das estratégias de legitimação da desigualdade, de modo que a educação lhe permita transcender os conceitos que o próprio sistema insiste em propagar como verdade universal. Candido destaca em "O Direito à Literatura", como citado na primeira parte desse artigo, que "a educação pode ser instrumento para convencer as pessoas de que o que é indispensável para uma camada social não o é para outra." (CANDIDO, 2004, p. 173). Ao contrário disso, por causa dos caminhos que aponta, dos desconfortos necessários que provoca, das cristalizações que desnaturaliza e do pensamento crítico que incita (como é o caso da peça acima), a literatura precisa deixar de ser uma mera disciplina constante no ementário para se tornar um fator indispensável de uma educação de qualidade, que ultrapasse as fronteiras do superficialismo que perpassa nossa realidade social.

Vivemos um contexto de práticas sombrias e de tentativas escancaradas de naturalização do preconceito, seja contra grupos entendidos como minorias, seja pela discriminação de classe social. Cada vez mais os discursos extremados e violentos, pautados numa falsa moral religiosa, tomam conta das ruas e se escancaram sem qualquer pudor. Diante disso, a demonização e repressão das manifestações artísticas tomam a linha de frente dessa guerra, o que comprova, em definitivo, o quanto a literatura, a história, a filosofia, o teatro, etc. ameaçam as estratégias de poder de uma casta que se julga superior. E por isso mesmo é que a construção literária se torna 
imprescindível e o ponto de partida para sua valorização se encontra na formação do leitor, no resgate de nossa história da literatura de modo mais consistente e, principalmente, na atualização dos grandes escritores, poetas e dramaturgos, com vistas ao fortalecimento da capacidade de análise dos nossos alunos. É na formação de uma população crítica, consciente de seu papel no mundo que formamos a trincheira necessária na luta contra todos os desmandos que avançam descontroladamente contra nossa geração.

\section{REFERÊNCIAS}

BOSI, A. Literatura e Resistência. São Paulo: Companhia das Letras, 2002.

CANDIDO, A. O Direito à Literatura. In: CANDIDO, Antonio. Vários Escritos. São Paulo/ Rio de Janeiro: Duas Cidades/ Ouro sobre Azul, 2004. p. 169-191.

CARPEAUX, O. M. História da Filosofia Ocidental (volume 1). Brasília: Senado Federal, Conselho Editorial, 2008.

COSSON, R. Letramento literário: Teoria e Prática. São Paulo: Contexto, 2006.

DIÉGUES JR, M. Literatura de cordel. Rio de Janeiro: Ministério da Educação e Cultura, 1977.

DREWS, W. Documento Histórico - Documento Atual (Prefácio). In: PISCATOR, E. Teatro Político. Trad. Aldo Della Lina. Rio de Janeiro: Editora Civilização Brasileira, 1968.

ECO, U. Leitura do Texto Literário: Lector in Fabula. Trad. Mario Brito. Lisboa, Portugal: Presença, 1979.

FLORY, A. V. Literatura e Teatro: Encontros e Desencontros Formais e Históricos. Revista JIOP $\mathrm{n}^{\circ}$ 1: Departamento de Letras - Editora UEM: 2010. Disponível em <http://www.dle.uem.br/revista_jiop_1/artigos/villibor.pdf> Acesso em 20 de set. 2019.

GOMES, D. Os Falsos Mitos. Coleção Dias Gomes (Volume 2). Rio de Janeiro: Bertrand Brasil, 1990.

GOMES, L.; GOMES, M. (org.). Dias Gomes - Encontros. Rio de Janeiro: Beco do Azougue, 2012.

ROSENFELD, A. O mito e o berói no moderno teatro brasileiro. São Paulo: Editora Perspectiva, 1982.

ROSENFELD, A. O Teatro Épico. São Paulo: Editora Perspectiva, 1985.

ROSENFELD, A. A arte do teatro: aulas de Anatol Rosenfield. São Paulo: Publifolha, 2009.

SZONDI, P. Teoria do Drama Moderno (1880-1950). Trad. Luiz Sérgio Repa. São Paulo: Cosac \& Naify, 2001.

ZILBERMAN, R. S.; SILVA, E. T. Literatura e Pedagogia: Ponto \& Contraponto. São Paulo/Campinas: Global/ALB, 2008. 